\title{
Halal Industry of Ukraine in the Period of Independence
}

\author{
Denys Brylov \\ Department of Theology and Religious Studies, National Pedagogical \\ Dragomanov University, Kyiv, Ukraine \\ dbrilyov@gmail.com
}

\begin{abstract}
This article analyzes how the halal industry in Ukraine began. One of the characteristic features in the development of Ukraine's halal industry is a confrontation between the main halal market players. These represent the transnational Sufi network al-Ahbash and the global Muslim Brotherhood, respectively. The first part of this article discusses the history of the halal industry in Ukraine and of the organizations that carry out halal certification. The second part is dedicated to one of the oldest halal certification centers - the Religious Administration of Muslims of Ukraine (DUMU - Dukhovne upravlinnia musul'man Ukraïny), associated with al-Ahbash. I reveal that for DUMU, the development of halal certification is primarily considered a part of the discourse on orthodoxy (i.e. practices of 'traditional' Islam) and how certification is undertaken is considered to bear on the religious status of DUMU in the eyes of Muslims. The economic aspect of halal is considered of secondary importance. In a third part of the article, I consider another halal operator, the Alraid Association, which is associated with the global Muslim Brotherhood. For this organization, halal certification is an important tool to promote the association's influence in business and the public sphere. In conclusion, I show that the halal industry in Ukraine is present and promising, but at present it aims mainly at large producers. Ordinary Muslims face certain troubles due to the underdevelopment of this sphere.
\end{abstract}

\section{Keywords}

halal industry - Islam in Ukraine - al-Ahbash - DUMU - Muslim Brotherhood - Alraid Association - DUMU-Umma 


\section{Introduction}

The halal industry is nowadays actively growing all over the world. In order to satisfy the demands of Muslim customers, companies strive to certify their products as conforming with the principles of the Shariah (i.e. allowed to be consumed by Muslims). Meanwhile, the Muslim countries of the Middle East and Northern Africa are among the largest food importers in the world: imported goods cover approximately $50 \%$ of their food needs. Even $10 \%$ of the region's wheat, one of its own major food products, is imported. The demand for food in this region is expected to increase as the population there grows yearly at a rate of approximately $3 \%$. This situation creates an opportunity for Ukraine to enter the Middle Eastern markets, the Gulf countries in particular, with its food products (Volovych et al. 2011: 5) - if they are considered permissible for Muslim consumption.

After the break-up of the Soviet Union, there has been a growing role of religion in Ukrainian society. The public sphere has been entered by religious organizations that were not registered on the territory of Ukraine during the Soviet period. These include Islamic communities. During Soviet times certain Muslim communities in Ukraine (first of all, those of Volga Tatars) were illegal and functioned only underground. After independence, these resurfaced, and other Muslims appeared in Ukraine through such processes as the return of Crimean-Tatar Muslims and the transmigration of Meskhetians from Central Asia. These communities have led to the development of a visible Islamic infrastructure in Ukraine. It includes, in particular, the development of the halal industry, encompassing catering establishments that meet halal requirements, brands with the corresponding certification, and certification structures.

At the same time, the development of the halal industry in Ukraine has its own economic and socio-historical characteristics. Among these are the export orientation of Ukrainian producer, the long absence of Muslims from public discourse (food producers simply did not know about the existence of such a category of consumers as Muslims), and a low level of religious knowledge among a significant part of local Muslims (the Muslims themselves had a poor idea of what halal is). Taken together, these mean that Muslims in Ukraine have not been the primary customers, real or imagined, for the local halal industry.

In my article, I analyze the activities of the two main halal certification centers associated with the most influential Islamic organizations among Ukrainian Muslims. These both have wide connections in the Islamic world. They are the Certification Center 'Halal' by the Religious Administration of Muslims of Ukraine (DUMU), and the Center for Research and 'Halal' Certification by the NGO Alraid Association. It should be noted that since 
2008 the Product Certification and Standardization Department 'Elal' (Halal) functions also alongside the Religious Administration of Muslims of Crimea (DUMK). However, this department issued the first halal certificate only in August 2013, ${ }^{1}$ and six months later, the Crimean muftiate entered the legal field of Russia. Therefore, in my article I do not consider it.

My article is based on data gathered during field research on Islamic infrastructure in Ukraine conducted in $2015^{-2020}$. It included participant observation, in-depth interviews with representatives of the Islamic community and the certification centers, and analysis of the press.

\section{Halal in Ukraine: Economic and Social-Historical Background}

Speaking about the current situation, first of all it should be noted that we still have no precise data on the numbers of Muslims in Ukraine or on the composition of particular Islamic communities. According to the last national census of 2001, there are 436,ooo ethnic Muslims (i.e. members of ethnic groups predominantly associated with Islam, irrespective of whether such individuals are believers or atheists). This amounts to about 0.9 percent of the overall population (Yarosh and Brylov, 2011). Representatives of various religious administrations of Muslims, as a rule, voice numbers that are three times higher than the census: $1-1.5$ million people.

The largest Muslim ethnic groups are Crimean Tatars (248,00o), Volga Tatars $(73,000)$, Azerbaijanis $(45,000)$, representatives of the North Caucasus ethnic groups (14,00o), Uzbeks (12,00o) and Turks/Meskhetians (approx. 10,000). Geographically, the largest Muslim community of Ukraine was in Crimea $(272,600$, including Sevastopol), followed by the Muslims of the Donetsk region (36,00o), Kharkiv (16,00o), Luhansk (15,000), Dnipropetrovsk (now Dnipro, 15,00o), Kherson (14,00o), Odessa (12,200), Zaporizhia (11,700), and Kyiv (10,900) (Bogomolov et al. 2006: 24).

The most important Islamic institutions consolidating a huge part of Muslim communities are: the Religious Administration of Muslims of Ukraine (Dukhovne upravlinnia musul'man Ukraïny - DUMU) in Kyiv; the Religious Administration of Muslims of Crimea (Dukhovne upravlinnia musul'man Krymu - DUMK) in Simferopol; the Religious Center of Muslims of Ukraine (Dukhovnyi tsentr musul'man Ukraïny - DTsMU) in Donetsk; the Religious

1 Muftiyat dal pervoe razreshenie na elyal-produkciyu [The muftiate gave the first permission for elyal-products]. Avdet, August 6, 2013. Available online, https://avdet.org/ru/2013/o8/o6/ muftiyat-dal-pervoe-razreshenie-na-elyal-produktsiyu/. Accessed August 30, 2020. 
Administration of Muslims of Ukraine 'Umma' (Dukhovne upravlinnia musul'man Ukraïny 'Umma' - DUMU-Umma) in Kyiv; the Religious Center of Muslims of Crimea (Dukhovnyitsentrmusul'man Krymu-DTsMK) in Eupatoria; and the Religious Administration of Independent Islamic Communities 'Kievskii Muftiat' (Relihiine upravlinnia nezalezhnykh musul'mans'kykh hromad Ukrainy - RUNMHU) in Kyiv.

After 2014, DUMK and DTsMK (members from which founded the Central Religious Administration of Muslims 'Tauride Muftiyat') were outside the legal field of Ukraine. DTsMU remained in zones of armed conflict in the self-proclaimed Donetsk People's Republic and Luhansk People's Republic. The remaining religious administrations - DUMU, DUMU-Umma and RUNM HU, as well as the Religious Administration of Muslims of the Autonomous Republic of Crimea (Dukhovne upravlinnia musul'man avtonomnoi respubliky Krym DUM ARK, registered at the end of 2017), and independent Muslim communities that are not part of any of these spiritual boards, continue to function on the territory of Ukraine, which is under Kyiv's control.

The NGO Alraid Association (officially the All-Ukrainian Association of Social Organizations 'Alraid' - AUASO Alraid) is ideologically, organizationally and financially connected with the global Muslim Brotherhood movement (Brylov 2014: 73-74). Because of its charitable-organization status, Alraid could not register as another muftiate in Ukraine. The solution to this problem was the establishment in 2008 of DUMU-Umma, which is seen as a 'front muftiate' for Alraid in Ukraine (Izmirli 2012).

At present, it is difficult to assess the total potential of the domestic market for halal products. Available estimates are based on the total number of Muslims in Ukraine and range from $\$ 1-2$ billion. As for the export potential of halal producers, it is estimated at $\$ 4-5$ billion. $^{2}$ The main and most promising direction of halal certification is with the certification of chicken meat. Ukraine is already a major producer, ranking 4th in the world for the export of this product, ${ }^{3}$ and already has an established presence in the large Middle Eastern markets. Countries of the Islamic world import almost half of

2 Ukrainskaya Halyal industriya: tekushaya situaciya $\mathrm{v}$ strane, perspektivy razvitiya na mezhdunarodnyh rynkah [Ukrainian Halal Industry: Current Situation in the Country, Development Prospects in International Markets]. Ukrhalal website, August 3, 2017. https:// ukrhalal.org/ukrainskaya-halyal-industriya-tekushhaya-situatsiya-v-strane-perspektivyrazvitiya-na-mezhdunarodnyh-rynkah/. Accessed September 3, 2020.

3 Ukraina voshla v top-5 mirovyh eksporterov kuryatiny - Minekonomiki [Ukraine entered the top 5 world exporters of chicken - Ministry of Economy]. Liga.Biznes, January 14, 2020. Available online, https://biz.liga.net/ekonomika/prodovolstvie/novosti/ukraina-voshla-vtop-5-mirovyh-eksporterov-kuryatiny---minekonomiki. Accessed August 28, 2020. 
all chicken produced in Ukraine. The largest importer of Ukrainian chicken meat is Saudi Arabia. ${ }^{4}$ Moreover, even with a general decrease in exports in the initial months of the COVID-19 pandemic, the supply of chicken increased by $5 \%$, with Saudi Arabia and the UAE becoming the top three global importers of Ukrainian chicken. ${ }^{5}$

The prospects for entering the market of Muslim countries has led to the development of the halal livestock industry, which would otherwise be unpromising in Ukraine. Some firms are switching completely to the production of halal products. According to the director of one of these companies, the main consumers of the products are Azerbaijan, Egypt and Turkey, and only $5 \%$ of the total volume is sold in the domestic market. What's more, halal meat in the domestic market is dominated by the residues suitable for the manufacture of sausages! ${ }^{6}$

Another important area is the halal certification of sunflower oil. In terms of exports, Ukraine ranks first in the world for this product. As with chicken meat, the trade in sunflower oil has been unaffected by the COVID-19 pandemic. The export of sunflower oil in 2020 increased by $10 \%$ compared to the same period in 2019, and among the main buyers of Ukrainian oil there are also countries of the Islamic world: Iraq occupies the 4 th position, and its share is $8.6 \%$ from the total volume of Ukrainian exports. ${ }^{7}$ Other major buyers of sunflower oil include the UAE and Malaysia.

At the same time, the economic attractiveness of obtaining halal certification for export products plays a negative role in the formation of a domestic market. According to the head of one of the largest halal certification centers, many of the products that receive the halal certificate are not supplied to the Ukrainian market at all, as it is economically impractical, due to the low

4 Saudovskaya Araviya stala osnovnym pokupatelem ukrainskoj kuryatiny [Saudi Arabia became the main buyer of Ukrainian chicken]. Liga.Biznes, May 30, 2019. https://biz.liga. net/ekonomika/prodovolstvie/novosti/saudovskaya-araviya-stala-osnovnym-pokupatelemukrainskoy-kuryatiny. Accessed January 30, 2020.

5 Ukraine's chicken meat export went up in Jan-Aug (2020). Latifundist, September 9, 2020. Available online, https://latifundist.com/en/novosti/51866-ukraina-uvelichila-eksportmyasa-ptitsy-s-nachala-goda. Accessed September 92020.

6 Vostok - delo tonkoe: v Ukraine osvaivayut standard «halal» dlya govyadiny [The East is a delicate matter: In Ukraine they master the halal standard for beef]. Ekonomika, September 20, 2018. Available online, http://economica.com.ua/article/77715520.html. Accessed January 30, 2020.

7 Ukraina ustanovila rekord po eksportu podsolnechnogo masla tankerami [Ukraine has set a record for the export of sunflower oil by tankers]. Liga.Biznes, September 22, 2020. https://biz.liga.net/all/prodovolstvie/novosti/ukraina-ustanovila-rekord-po-eksportupodsolnechnogo-masla-infografika. Accessed September 23, 2020. 
purchasing power of Ukrainian citizens and the instability of the hryvnia exchange rate. For example, the largest producer of sunflower oil in Ukraine, KERNEL, which supplies several brands of halal sunflower oil (including premium ones) to Arab countries, does not sell any products with halal certification in the domestic market (Interview, September 2020, Kyiv). Thus, we can say that the export orientation of the Ukrainian manufacturer has become an obstacle to the formation of the domestic halal market.

At the same time, there are other factors that hinder the development of the halal industry in Ukraine. Specifically, Muslim communities - and individual Muslims - remain in the shadows of public space. Since 1989, government agencies began registering Islamic communities, and Muslims have been able to practice their rituals openly and without fear, including food-related practices. However, the integration and development of Muslim communities is hindered by Ukraine's historical background. First of all, it should be noted that Ukraine has a Christian majority, and all non-Christian confessions are perceived ambiguously by the majority of the population and by the authorities. Official Muslim communities operated on the territory of Ukraine from the end of the nineteenth century, primarily in such centers as Kyiv, Kharkov, Odessa and Donetsk region (Brylov 2017a: 155), but in the decades after the Second World War, the ombudsmen for religious affairs in Soviet Ukraine saw it as their task to prevent the registration of Muslim communities, adhering to the rule - 'there is no Islam in Ukraine' (Interview, September 2015, Kyiv).

Moreover, Muslims have long been perceived with caution because of the complex historical relations with Ukraine's indigenous Muslim population the Crimean Tatars - between the Ukrainian lands and the Crimean Khanate. Until now, Ukraine has one of the highest levels of Islamophobia in Europe. According to a Pew Research Center report, only $25 \%$ of Ukrainians would agree to see a Muslim as a member of their family; in neighboring Russia, this percentage is 34 (Pew Research Center 2018). Under the heading, 'Regional tolerance, xenophobia and human rights in 2012', another report gives an index of interethnic distance in 2012 as 4.5 out of a maximum 7. This index characterizes interethnic, interracial and international relations in Ukrainian society as 'alienating'. In Western Ukraine, xenophobia is primarily directed at Arabs, Africans, Crimean Tatars, and Jews, while in Eastern Ukraine it targets Asians, Arabs, and the representatives of Western European and Atlantic national and cultural groups (Germans, French, Americans, Canadians). The results of the research are an indication that Muslim ethnicities are at the top of the list. In general, one can agree with opinion the head of the Group for Monitoring Minority Rights, Vyacheslav Likhachev, who thinks that Islamophobia is one of the most prominent forms of xenophobia in Ukraine (Brylov 2016: 268-269). 
In such a national context, many Muslims prefer not to identify very publicly with their faith. ${ }^{8}$ Explicit purchase, consumption, or use of halal products therefore has little appeal.

Another problem that negatively affects the development of the halal industry is the secularization of the Soviet period, which affected all groups of Muslims in Ukraine. According to Idil Izmirli (Izmirli 2012), most Ukrainian Muslims who grew up during the Soviet era did not know the basic tenets of Islam, nor did they understand the differences between the various Islamic trends and ideologies. The majority of the traditional Crimean Tatars seem to profess what Izmirli calls 'cafeteria Islam', picking and choosing Islamic teachings based on their own life-styles and interpretations. As a result, many Crimean Tatars drink alcohol even during Ramadan, and they eat pork; but they may refuse to touch a dog because it is considered haram (forbidden). For many Ukrainian Muslims and in general post-Soviet Muslims, everything that is not pork is halal. For example, in Central Asia (where Crimean Tatars, who make up the majority of Ukrainian Muslims, were deported for almost $5^{\circ}$ years) vodka drinking became an integral part of 'Muslim' celebrations during the Soviet period, and has since been assimilated to national tradition (Khalid 2014: 101).

For a long time, the halal industry in Ukraine was not developed even in the food products segment. Halal food could be found only in areas that were densely and exclusively populated by Muslims; in the houses of prayers (musallas) and a few mosques. Even in the early 20oos, the halal industry was weakly developed throughout most of Ukraine, and believers could hardly buy products that complied with Sharia norms. Some $55 \%$ of interviewed Muslims noted that they have problems buying halal goods (Havrilova et al. 2011). The same study produced a figure of $42 \%$ of interviewees who did not report such problems, but the researchers believed that these respondents were aware of the shops near mosques and Muslim centers. Nevertheless, these small shops cannot satisfy the demands of all Muslims (Havrilova et al. 2011).

The underdevelopment of the halal certification system in Ukraine has led to attempts by Russian Islamic organizations to take control of this area. In 2012 the delegation of the International 'Halal' Certification Centre of the Russian Mufti Board (Sovet muftiev Rossii - SMR), headed by CEO Aidar Gazizov, paid a working visit to Ukraine. This visit to Ukraine was part of the SMR program for the creation and control of a single 'halal' economic space in the territory of

8 The situation began to change in 2014, when in the Russian-Ukrainian conflict, Crimean Tatars and natives of the North Caucasus, hostile against Russia, took the side of Ukraine, which contributed to the improvement of attitudes towards Muslims in Ukraine. 
the cis countries (Bagautdinova 2012). During the visit, the delegation reached an agreement with Kanafia Husnutdinov, the head of RUNMHU, to open the Center's office in Kyiv. At the same time, the main customer of the halal certification of the new center was the ROSHEN confectionery concern, owned by Petro Poroshenko who later became president of Ukraine. The certification procedure was passed by the enterprises of this company, which are located in Vinnitsa, Kyiv, Kremenchug and Mariupol. Nevertheless, with the beginning of the Russian-Ukrainian conflict over Crimea, the cooperation was phased out.

\section{'Battlefield Halal'}

The development of the halal industry in Ukraine is characterized by factors beyond economics, demographics and history. There are also institutional and ideological factors from within Islam that affect its development. DUMU and Alraid (along with the DUMU-Umma) form two different religious discourses that are in competition with each. Each takes part in a transnational Islamic structure that has a long history of confrontation with the other. According to Mustafa Kabha and Haggai Erlich, this a confrontation between those striving for the political victory of Islam, widely referred to as Wahhabis, and the adherents of Sufism who favor the kind of political coexistence between Muslims and Christians personified by al-Ahbash (Kabha and Erlich 2006: 519-518). Being irreconcilable ideological opponents, they project their conflict onto Ukrainian everyday life, including the domain of halal certification.

As the oldest religious association of Muslims of Ukraine, which includes communities that informally operated on the territory of Ukraine in the Soviet period, DUMU is a part of the transnational Sufi network, widely known as Al-Ahbash, or habashiyya, with both terms referring to the Jam'iyyat al-mashari' al-khayriyya al-Islamiyya (Association of Islamic Charitable Projects - AICP). The term al-Ahbash (lit. the Ethiopians), used to describe the movement's members, is connected with the name (nisba) of the movement founder Abdullah Al-Harari al-Habashi, an Ethiopian native.

Al-Ahbash adherents mostly follow the Shafi'i madhhab (law school), whereas in matters of faith they tend to be mostly Asharite. One of the most important tenets of the al-Ahbash ideology is the recognition of the complete Shariah legitimacy of Sufism, along with its main rituals and practices such as dhikr (mention of God) and ziyarat (visits to the graves of saints and prophets). The ideology of al-Ahbash can be described using the concept of 'traditional Islam' proposed by K. Mathiesen which is based on the hadith Jibril that divides 
the religion into islam, iman and ihsan..$^{9}$ Each of these represents an anthropological aspect, islam (body/practice), iman (mind) and ihsan (spirit/soul), as well as subfields of revealed knowledge, traditions, practices and institutions. This tripartite structure further contextualizes traditional Islam's discourse of orthodoxy in three major discursive fields of contention, islam/fiqh, iman/' $a$ qida and ihsan/tasawwuf (Sufism) (Mathiesen 2013: 217).

The mufti of DUMU, Sheikh Ahmed Tamim, is Lebanese by origin and was a student of Abdullah Al-Harari. It was Tamim who became one of the first $\mathrm{Al}$-Harari supporters in Ukraine; later he was actively engaged in disseminating his teacher's ideas.

DUMU became the first Ukrainian organization to issue halal certificates. According to Sheikh Ahmed Tamim himself, the first certificates were issued in 1994 to a sunflower oil producer who needed halal certification to enter the Indonesian market (Interview, September 2020, Kyiv). Until 2011, DUMU itself carried out halal certification, however, due to the increase in the number of clients, it became necessary to establish a separate certification center.

Today the Certification Center 'Halal' by DUMU is an independent organization with the status of an international institution. ${ }^{10}$ It certifies the compliance of production processes with Sharia law. It also organizes and carries out the certification of goods and services, guaranteeing an independent and professional evaluation of compliance with the 'halal' standard.

The Center sets its main goals as follows:

- to check and confirm that halal-marked products do not contain forbidden ingredients;

- to check and confirm that halal-marked meat products are in fact made from the meat of the allowed animals that were slaughtered in compliance with Sharia requirements;

- to increase the quality of goods and services;

- to protect customers from negligent producers and service providers;

- to promote the competitiveness of 'made in Ukraine' products on the global market (primarily in Muslim countries) (Brylov 2017b: 112).

Representing a conservative group that zealously defends the Ash'ari doctrine from modern Salafism and the reformed figh of the Muslim Brotherhood, and strictly following Shaf'i law, Ukrainian Habashites consider halal norms primarily as a religious issue, not an economic one. As the head of the Certification Center 'Halal' by DUMU, Ruslan Borichevskyi, noted, very often

9 For more information about the discourse of the 'traditional Islam' of DUMU, see Brylov (2018).

10 The official website is www.halal.ua. 
they refuse halal certification to Ukrainian manufacturers because production conditions and raw materials do not meet all Shari'ah requirements. (As a rule, DUMU refers to the Shafi'i tradition, less often - Hanafi). After that, many customers turn to the competing structure of Alraid (or DUMU-Umma), which stipulates milder conditions.

Despite the fact that the conservative position and strict requirements for the products themselves and production conditions reduce the economic competitiveness of the DUMU certification center, their close ties with Sufi circles in the Islamic world save the situation. The halal certificate issued by DUMU is recognized in almost in all countries where Sufism has a strong position. For example, the Certification Center 'Halal' at DUMU for a long time was the only one in Ukraine that had accreditation issued by EIAC (Emirates International Accreditation Center) and JAKIM (Department of Islamic Development Malaysia). This means that DuMU-certified products have stronger access to the markets of Muslim countries in the Middle East and Southeast Asia. ${ }^{11}$

The main competitor of DUMU in the halal industry is the Alraid Association and the DUMU-Umma connected with it. An unconditional authority for the Alraid and the Dumu-Umma is the leading ideologist of the Muslim Brotherhood, Yusuf al-Qaradawi, who has a critical attitude toward taqlid and consequently toward the rules of one madhhab. Following him, Ukrainian Muslim brothers likewise do not associate Islam with the religious tradition of any particular Muslim peoples. This was stressed by DUMU-Umma mufti Said (Serhei) Ismagilov in my interview with him. In the words of S. Ismagilov, religious views and practices that do not conform to the strict limits of orthodox Sunnism, become a private matter for individual believers (Brylov 2014: 73). Such a light attitude to halal standards can be seen in the activities of the halal cafe 'Jerusalem' at the Islamic Cultural Center of Kyiv (in Alraid's headquarters), whose director indicated that even though the Qur'an categorically forbids alcohol, if a person who came with a bottle of vodka, he would not be expelled from the cafe: 'We understand that we do not live in the United Arab Emirates, and respect Ukrainian customs' (Siyak 2008).

In 2012, together with the DUMU-Umma, Alraid registered the Centre for Research and 'Halal' Certification Alraid (CRHC Alraid). This Centre defines its goals as follows:

- to provide the Ukrainian food market with halal goods, available for Muslim customers;

11 Dostijenia [Achievements] 2019. Certification Center 'Halal' website https://halal.ua/jakim. Accessed January 30, 2020. 
- to promote the export of Ukrainian goods to the markets of Arab and Muslim countries, [and] build bridges between the Islamic world and Ukraine;

- to promote sales of 'made in Ukraine' goods that comply with halal standards;

- to create workplaces for Muslims. ${ }^{12}$

Nevertheless, Alraid is accused of insufficiently strict standards. In May 2016, numerous reports appeared in Ukrainian media that that the United Arab Emirates had forbidden the import of Ukrainian halal-certified food. ${ }^{13}$

As it turned out, the UAE had not forbidden the import of Ukrainian food products, nor had they ever expressed concerns about quality. Rather, the Alraid Center had lost the right to issue halal certificates. Yet this in itself was unlikely to stop Ukrainian exports; before this organization had gained certification rights in February 2014, Ukrainian exporters had used other means to obtain such certificates, including alternative certification centers in Ukraine and abroad. ${ }^{14}$

In order to compensate for serious image losses and fulfill its business obligations to Ukrainian enterprises that had already passed certification at the CRHC Alraid, the association registered several new halal certification centers in 2016. In addition, DUMU-Umma founded a separate certification center 'Halal Global Ukraine'. Its mission statement read: 'to help Ukrainian producers to expand their markets and develop export connections with Muslim countries, to protect customers of the Halal products and services made in Ukraine' (O nas 2020).

In December 2016, the Ukrainian Association of the Halal Industry 'Ukrhalal' was created on the base of CRHC Alraid. It united CRHC Alraid and 'Halal Global Ukraine'.

12 Tsentr doslidzhen ta sertyfikatsii Khalyal [Halal Research and Certification Center]. June 12, 2016. Tsentr doslidzhen ta sertyfikatsii Khalyal website, http://halal.org.ua/]. Accessed January 3o, 2020.

13 Emiraty zaboronyly import produktsii z Ukrainy [The Emirates banned the import of products from Ukraine]. Korrespondent, May 3o, 2016. Available online,https:// ua.korrespondent.net/ukraine/3689963-emiraty-zaboronyly-import-produktsii-z-ukrainy. Accessed January 30, 2020.

14 Emiratska storona sprostuvala informatsiiu pro pryzupynennia importu do OAE ukrainskoi produktsii. [The Emirati side has denied information about the suspension of imports into the UAE of Ukrainian products]. State Service of Ukraine on Food Safety and Consumer Protection website, June 10, 2016. http://consumer.gov.ua/News/154/Emiratska_storona_ sprostuvala_informatsiyu_pro_prizupinennya_importu_do_OAE_ukrainskoi_produktsii. Accessed January 30, 2020. 
The importance and the promise of the halal industry in Ukraine is even noted in the 'Social Conception of the Ukrainian Muslims', the program document of the Alraid Association and DUMU-Umma, which was co-signed by some Ukrainian Muslim organizations. The document reads: 'Taking into account the practices of Islamic banking, this sector of the economy is one of the most promising; with the development of the Halal industry, it is the priority for the activities of Islamic organizations. ${ }^{\prime 15}$

Certifying many large Ukrainian producers (primarily meat producers and confectionery corporations), Alraid and DUMU-Umma consider halal an instrument of influence in the public sphere. For example, in October 2017, the Ukrainian Association of the Halal Industry 'Ukrhalal' sent an open letter to representatives of the largest retailers in Ukraine with a proposal to help them create and maintain a 'single halal shelf' to display products that have the appropriate certificate.

\section{Conclusion}

For now, the halal industry in Ukraine aims mainly at large producers. Meanwhile, ordinary Muslims face certain troubles due to the underdevelopment of the halal industry. Namely, Islamic banking and halal healthcare are absent; halal catering establishments and kindergartens, and schools with a halal food option are underdeveloped. Nevertheless, lately, cafes and restaurants that position themselves as 'halal' have appeared. Mainly, these establishments represent Arab or Turkish cuisine and are controlled by such nationals. Large Islamic organizations such as DUMU and Alraid (together with DUMUUmma) are opening private schools that serve halal food. Halal infrastructure is developing actively in places where Crimean Tatars who left Crimea after the annexation live compactly.

Hence, one can state that the halal industry in Ukraine is present and promising. This is proved by the work of 28 organizations that issue halal certificates. It should be noted though, that most of them are not connected to the existing religious administrations, so they cannot guarantee that their certificates comply with Sharia standards. Despite the growing popularity of halal certification, these products are mainly exported. This is why the

15 Sotsialna kontseptsiia musulman Ukrainy [Social concept of Muslims of Ukraine], 2017. DUMU-Umma website, https://umma.in.ua/ua/node/189o. Accessed January 30, 2020. 
internal market will not be satiated for a long time. In the same time, the competition between the certification centers could lead to the development of an efficient certificate-issue algorithm and the enhancement of the performance of such centers.

\section{References}

Bagautdinova, D. (2012). Halyal: pokorenie SNG [Halal: the conquest of the CIS]. Medina al-Islam, 133. Available online, http://www.idmedina.ru/medina/?4868. Accessed January 30, 2020.

Bogomolov, Alexander, Serhei Danylov, Ihor Semivolos, and Halina Iavorskaia (2006). Islamskaia identichnost' $v$ Ukraine [Islamic identity in Ukraine]. Kyiv: ID Stilos.

Brylov, Denis (2014). Ukrainian modernist groups in an international context. Anthropology \& Archeology of Eurasia, 53(3): 72-80.

Brylov, Denis (2016). Transformed perceptions of Islam and Muslims in Ukraine in the wake of the Social and political changes caused by Euromaidan. In, Aslan, Adnan, Ranja Ebrahim, and Marcia Hermansen, (eds.), Islam, Religions, and Pluralism in Europe, pp. 267-284. Wiesbaden: Springer VS.

Brylov, Denis (2017a). 'Zapretnyi Islam' v sovetskoi Ukraine ['Forbidden Islam' in Soviet Ukraine]. Islamology, $7(2): 150-163$.

Brylov, Denis (2017b). Instytualizatsiia musulmanskoi spilnoty Ukrainy: Dukhovne upravlinnia musul'man Ukrainy (DUMU) [The institutionalization of the Muslim community of Ukraine: The religious Administration of Muslims of Ukraine (DUMU)]. Naukovyi chasopys Natsionalnoho pedahohichnoho universytetu imeni M.P. Drahomanova. Seriia 7: Relihiieznavstvo. Kulturolohiia. Filosofiia [Scientific Journal of National Pedagogical Dragomanov University. Series 7: Religious Studies. Cultural Studies. Philosophy], 38(51): 106-114.

Brylov, Denis (2018). Islam in Ukraine: The language strategies of Ukrainian Muslim communities. Religion, State \& Society, 46(2): 156-173.

Havrilova, Natalia, Oleh Kyselov, and Tetiana Khazyr-Ohly (2011). Svitohliadnopolitychni pohliady musulman Ukrainy (za materialamy sotsiolohichnoho doslidzhennia) [Worldview and political views of Muslims of Ukraine (based on sociological research)]. Relihiia v Ukraini website, https:/www.religion.in.ua/ main/analitica/12445-svitoglyadno-politichni-poglyadi-musulman-ukrayini-zamaterialami-sociologichnogo-doslidzhennya.html. Accessed January 30, 2020.

Izmirli, Idil (2012). Competing narratives of Islam in Post-Soviet Ukraine against the background of Global Islamic Movements. IREX Research Brief. Available online, http://www.irex.org/resources/competing-narratives-islam-post-soviet-ukraineagainst- background-global-islamic-movements. Accessed August 30, 2015. 
Kabha, Mustafa and Haggai Erlich (2006). Al-Ahbash and Wahhabiyya: Interpretations of Islam. International Journal of Middle East Studies, 38(4): 519-538.

Khalid, Adib (2014). Islam after Communism: Religion and Politics in Central Asia. Berkeley: University of California Press.

Mathiesen, Kasper (2013). Anglo-American 'traditional Islam' and its discourse of Orthodoxy. Journal of Arabic and Islamic Studies, 13: 191-219.

O nas. [About Us.] (2020). Accessed January 30 2020, from the Tsentr Sertifikatsii «Halal Global Ukraine» website http://www.halalglobal.in.ua/o-nas/.

Pew Research Center (2018). Eastern and Western Europeans differ on importance of religion, views of minorities, and key social issues. Available online, https://www. pewforum.org/2018/10/29/eastern-and-western-europeans-differ-on-importanceof-religion-views-of-minorities-and-key-social-issues/. Accessed January 30, 2020.

Siyak, Ivan (2008). Halyalnyiy Kiev: eda dlya pravovernyih musulman [Halal Kiev: Food for faithful Muslims]. Nash Kiev website, https://nashkiev.ua/zhournal/vkousnayaeda/halyal-nyy-kiev-eda-dlya-pravovernyh-mousoul-man.html. Accessed January 30, 2020.

Volovych, Olexii et al. (2011). Stratehiia aktyvizatsii spivpratsi Ukrainy z derzhavamy Perskoi zatoky: analitychna dopovid [Strategy of Enhancing Cooperation of Ukraine with the Gulf States: An Analytical Report]. Odesa: Feniks.

Yarosh, Oleh and Denis Brylov (2011). Muslim communities and Islamic network institutions in Ukraine: Contesting authorities in shaping of Islamic localities. In , Katarzyna Górak-Sosnowska (ed.), Muslims in Poland and Eastern Europe: Widening the European Discourse on Islam, pp. 252-265. Warsaw: University of Warsaw. 